Ocean Sci., 10, 1-16, 2014

www.ocean-sci.net/10/1/2014/

doi:10.5194/os-10-1-2014

\title{
Changes in ventilation of the Mediterranean Sea during the past 25 year
}

\author{
A. Schneider ${ }^{1}$, T. Tanhua ${ }^{1}$, W. Roether ${ }^{2}$, and R. Steinfeldt ${ }^{2}$ \\ ${ }^{1}$ GEOMAR Helmholtz Center for Ocean Research Kiel, Kiel, Germany \\ ${ }^{2}$ Institute of Environmental Physics, University of Bremen, Bremen, Germany
}

Correspondence to: T. Tanhua (ttanhua@geomar.de)

Received: 25 July 2013 - Published in Ocean Sci. Discuss.: 20 August 2013

Revised: 12 December 2013 - Accepted: 14 December 2013 - Published: 27 January 2014

\begin{abstract}
Significant changes in the overturning circulation of the Mediterranean Sea has been observed during the last few decades, the most prominent phenomena being the Eastern Mediterranean Transient (EMT) in the early 1990s and the Western Mediterranean Transition (WMT) during the mid-2000s. During both of these events unusually large amounts of deep water were formed, and in the case of the EMT, the deep water formation area shifted from the Adriatic to the Aegean Sea. Here we synthesize a unique collection of transient tracer (CFC-12, $\mathrm{SF}_{6}$ and tritium) data from nine cruises conducted between 1987 and 2011 and use these data to determine temporal variability of Mediterranean ventilation. We also discuss biases and technical problems with transient tracer-based ages arising from their different input histories over time; particularly in the case of time-dependent ventilation.

We observe a period of low ventilation in the deep eastern (Levantine) basin after it was ventilated by the EMT so that the age of the deep water is increasing with time. In the Ionian Sea, on the other hand, we see evidence of increased ventilation after year 2001, indicating the restarted deep water formation in the Adriatic Sea. This is also reflected in the increasing age of the Cretan Sea deep water and decreasing age of Adriatic Sea deep water since the end of the 1980s. In the western Mediterranean deep basin we see the massive input of recently ventilated waters during the WMT. This signal is not yet apparent in the Tyrrhenian Sea, where the ventilation seems to be fairly constant since the EMT. Also the western Alboran Sea does not show any temporal trends in ventilation.
\end{abstract}

\section{Introduction}

The circulation and ventilation in the Mediterranean Sea have been studied for several decades (e.g. Wüst, 1961; Malanotte-Rizzoli and Hecht, 1988; Roether and Schlitzer, 1991; Roether et al., 1998a; Lascaratos et al., 1999; Millot, 1999; Pinardi and Masetti, 2000; Theocharis et al., 2002). Figure 1 shows a map of the Mediterranean Sea with the main basins and geographical terms that are used in this report. The Mediterranean Sea is well ventilated in comparison to the world ocean, and is characterized by two deep overturning circulation cells and one shallow cell. Surface water from the Atlantic Ocean enters the Mediterranean basin through the Strait of Gibraltar, forming the upper arm of the shallow overturning circulation. This water flows towards the east and on its way salinity and density increase. In the Levantine basin in the eastern Mediterranean the density has reached such an extent that the water sinks to form the socalled Levantine Intermediate Water (LIW). The LIW flows back into the opposite direction in a few $100 \mathrm{~m}$ depth, to leave the Mediterranean Sea again through the Strait of Gibraltar. Exchange of the deep waters between the west and the east basin is inhibited by the shallow Sicily Channel $(<500 \mathrm{~m})$ and a rather independent deep water circulation takes place in the two basins. In the eastern basin, the Eastern Mediterranean Deep Water (EMDW) is regularly formed in the South Adriatic Sea, where high salinity waters get cooled in winter, reaching enhanced densities; after deep convection it flows over the Otranto sill into the Ionian basin to spread south and east (Wüst, 1961; Roether and Schlitzer, 1991; Schlitzer et al., 1991). In the western basin, a similar process takes place in the Gulf of Lyons forming the Western Mediterranean 


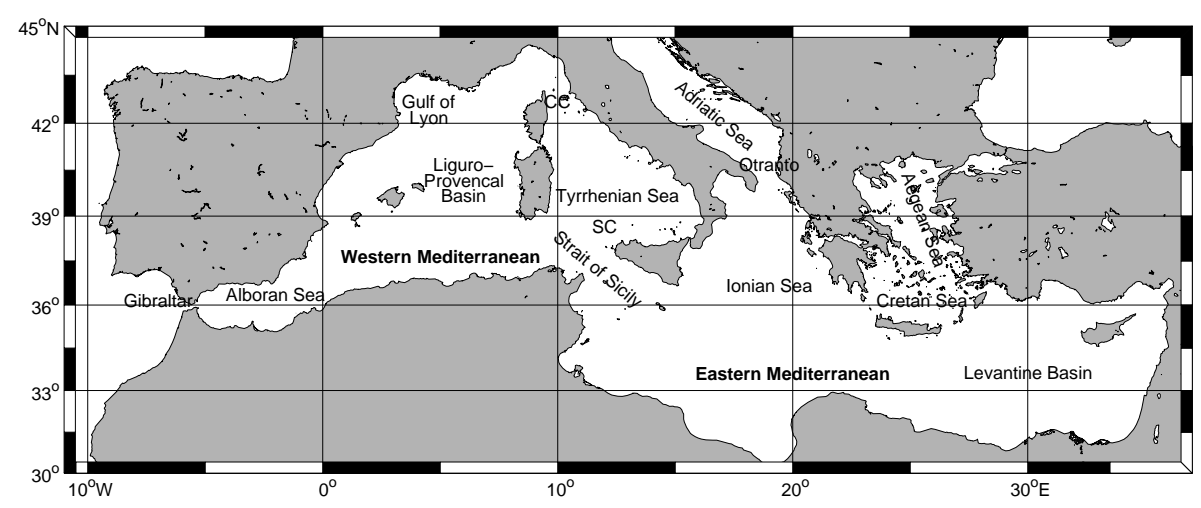

Fig. 1. Main basins and straits in the Mediterranean Sea mentioned in this article $(C C=C$ Corsica Channel, $S C=S a r d i n i a ~ C h a n n e l)$. Schematic of main circulation patterns and water transformation regions can be found in the rich literature on the Mediterranean Sea (e.g. Wüst, 1961; Robinson et al., 2001; Bergamasco and Malanotte-Rizzoli, 2010).

Deep Water (WMDW). Here, the highly saline LIW acts as a preconditioner for deep water formation (MEDOC Group, 1970; Leaman and Schott, 1991).

In the following we further describe certain water masses and processes and explain changes that occurred in the "classical" circulation pattern. Although, as described above, the eastern basin is subject to relatively fast deep water formation, a slowly ventilated water body is found between $1200 \mathrm{~m}$ and $2600 \mathrm{~m}$ depth. It is replenished by upwelling of bottom water and mixing with overlying water (Roether and Schlitzer, 1991; Schlitzer et al., 1991). Up to the early 1990s, Aegean-derived water appeared to be limited to forming an intermediate water mass, the so-called Cretan Intermediate Water (CIW), which is found below the LIW at depths around 500-1200 m (Schlitzer et al., 1991). However, a cruise in 1995 noticed strong changes in the deep water formation and circulation compared to 1987 (Roether et al., 1996), now known as the Eastern Mediterranean Transient (EMT). Enhanced salinities of subducting surface water in the Aegean Sea had led to water flowing out of the Aegean Sea that was dense enough to sink down to the bottom of the main eastern basin. This new Aegean deep water was formed at distinctly larger rates (7 yr average $\sim 1 \mathrm{~Sv}$ (Roether et al., 1996) (Sverdrup; $1 \mathrm{~Sv}=10^{6} \mathrm{~m}^{3} \mathrm{~s}^{-1}$ ) and maximum rate $\sim 3 \mathrm{~Sv}$ in 1993 (Roether et al., 2007)) than the Adriatic source previously $(\sim 0.3 \mathrm{~Sv}$ (Schlitzer et al., 1991)). The EMT was triggered by the presence of unusually saline water in the Cretan Sea followed by unusually cold conditions (e.g. Lascaratos et al., 1999). The Aegean outflow led to an uplift of the EMDW and the overlying water masses. Furthermore, the massive input of near-surface water containing large amounts of dissolved organic carbon accelerated the oxygen consumption at depth considerably (Klein et al., 2003).

In the Tyrrhenian Sea, subsurface waters from the eastern and western Mediterranean meet. From the east, LIW and transitional Eastern Mediterranean Deep Water (tEMDW; mixing regime between LIW and EMDW) enter through the
Sicily Channel, spreading along the northern Sicily slope (Sparnocchia et al., 1999). From the west, the WMDW enters at greater depth via the Sardinian Channel $(\sim 1900 \mathrm{~m})$ (Astraldi et al., 1996). The tEMDW and the WMDW mix and form the Tyrrhenian Deep Water (TDW), whereas most of the shallow LIW leaves via the Sardinian and the Corsican Channels. The TDW circles cyclonically in the Tyrrhenian Sea and leaves via the Sardinian Channel against the inflowing WMDW (Millot, 1999). During the EMT, the inflow into the Tyrrhenian Sea through the Sicily Channel showed increased salinities with a maximum in 1992-1993, which goes along with enhanced input rates (Gasparini et al., 2005). The increased density of the Sicily Channel overflow consequently led to enhanced downward mixing into the deep Tyrrhenian basin and also changed the properties of the TDW (Gasparini et al., 2005).

As mentioned before, in the western basin the deep water formation is dependent on the salt content of the LIW layer as a cyclonic gyre in the Gulf of Lyon brings highsalinity intermediate water close to the surface. Preconditioned by this process, the stability of the water column is effectively reduced and during winter-cooling the dense water can sink to the bottom (Gascard, 1978). Accordingly, the salinity changes induced by the EMT influenced the deep water formation in the western basin. Recent observations showed a significant increase in salt and temperature in intermediate and deep waters of the western Mediterranean, which has been attributed to the propagation of the EMT signal from the eastern to western basin (Gasparini et al., 2005; Schröder et al., 2006). Due to extreme forcing in the winters 2004/2005 and 2005/2006 (high heat loss, little precipitation, persistent winds) the deep convection was remarkably strong, leading to enhanced salinity and temperature over almost the entire deep basin up to about $1600 \mathrm{~m}$ depth (Schröder et al., 2008). The result of these events is referred to as the Western Mediterranean Transition (WMT). Similar to the EMT, Schröder et al. (2008) also noted a WMT-induced uplift of the isopycnals in the western basin. 


\section{Ventilation age concepts}

One way to estimate ventilation times is via water mass ages obtained with the help of transient tracers. The comparison of tracer data and the derived ages over time can provide information on temporal changes in ventilation. Water mass ages are defined as the time elapsed since a water parcel left the mixed layer. In the Mediterranean Sea the renewal timescales of different water bodies are relatively short. For example, the ventilation ages has been estimated to be 10 $20 \mathrm{yr}$ for the LIW (Stratford and Williams, 1997), 70-150 yr for the EMDW (Roether and Schlitzer 1991; Stratford et al., 1998) and $40 \mathrm{yr}$ for the WMDW (Stratford et al., 1998), although based on different assumptions than the tracer framework used in this study, and therefor not directly comparable, see discussion below. The anthropogenic tracers CFC$12, \mathrm{SF}_{6}$ and tritium can provide information on decadal to inter-decadal timescales and thus they are suitable for the Mediterranean Sea. Their input histories are shown in Fig. 2. The concepts of the age calculations we use are shortly described in the following.

The numerous nuclear bomb tests in the 1950s and early 1960s introduced large amounts of tritium into the environment, most of which entered the ocean, primarily by vapor exchange between the low troposphere and the water surface (Weiss and Roether, 1980). Tritium has a half-life of $12.43 \mathrm{yr}$ and decays into the stable isotope ${ }^{3} \mathrm{He}$, which, combined with tritium, can yield water mass ages - the tritium- ${ }^{3} \mathrm{He}$ age. We use the procedure of Roether et al. (1998b, 2013a) to separate the tritiugenic portion from a background of atmospherederived ${ }^{3} \mathrm{He}$ and a contribution released from the ocean floor (terrigenic ${ }^{3} \mathrm{He}$ ). Together with the measured tritium concentration and its half-life, the time when the decay started (i.e. after leaving the mixed layer) can be determined. By now most of the nuclear-weapon produced tritium has decayed, limiting its future uses. The chemically inert tracers CFC-12 and $\mathrm{SF}_{6}$ have (or had) monotonically increasing concentrations in the atmosphere (in case of CFC-12 concentrations peaked in 2002 and are now decreasing). The apparent CFC12 (or $\mathrm{SF}_{6}$ ) tracer age is defined as the elapsed time since the observed interior concentration was equal to the surface concentration, which is assumed to be in solubility equilibrium with the atmosphere. All tracer ages are affected (i.e. biased) by mixing (see below and Sonnerup, 2001).

Another way to calculate water mass ages is the transit time distribution (TTD) method (Hall and Plumb, 1994), which does account for mixing and thus represents a more realistic mean age. For steady transport, the TTD can be approximated by an inverse Gaussian function (IG) (Waugh et al., 2004) and with the help of two independent tracers the two variables ( $\Delta=$ width and $\Gamma=$ mean age) of the IG can be constrained. However, since we use the tracers separately, a constant ratio between $\Delta$ and $\Gamma$ has to be assumed. An extension of the TTD method is the approximation by a 2IG TTD (the summation of two inverse Gaussian functions) (Waugh

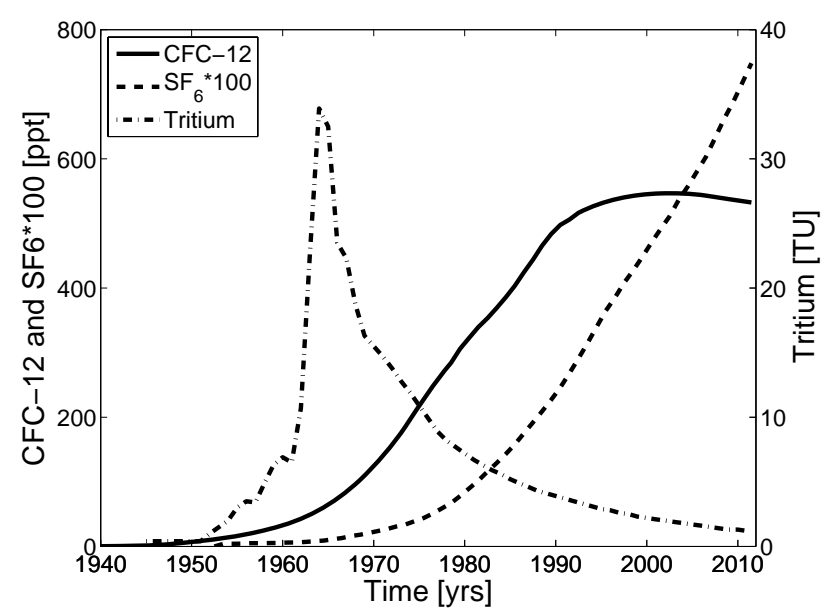

Fig. 2. Surface water input histories of $\mathrm{CFC}-12, \mathrm{SF}_{6}$ and tritium. For $\mathrm{CFC}-12$ and $\mathrm{SF}_{6}$ the atmospheric mixing ratios in ppt (Bullister, 2011) are assumed to be in $100 \%$ equilibrium with the Mediterranean surface water. The tritium input history is based on observations and taken from R. Steinfeldt (unpublished data).

et al., 2003), which allows for mixing of two totally different water masses (e.g., a young and an old water mass which mix during deep water formation). In that case the percentages of both water masses can be constrained by an additional third tracer. For the Mediterranean Sea several scenarios of 1IG and 2IG TTDs have been tested for the year 2011 when the three tracers $\mathrm{CFC}-12, \mathrm{SF}_{6}$ and tritium were available (Stöven and Tanhua, 2013).

In this study we compare salinity, temperature, oxygen as well as apparent tracer ages and mean ages (from the 1IG TTD approach) over a period of $25 \mathrm{yr}$ to detect changes in the circulation. We also address shortcomings of the different tracer age methods.

\section{Data and methods}

\subsection{Tracer data}

Table 1 lists the cruises from which tracer data were used for this work. On all cruises, the tracers CFC-12 and tritium were measured, which we use in this study. Additionally, for 2011 measurements of $\mathrm{SF}_{6}$ are available, and these data are used as well.

Sampled stations of Meteor 31/1 (M31/1), Meteor 51/2 (M51/2) and Meteor 84/3 (M84/3) cover the entire Mediterranean Sea (although the focus of the first two was the eastern Mediterranean). Meteor 5/6 (M5/6), Aegaeo M4WF (Aegaeo98) and Meteor 44/4 (M44/4) are restricted to the eastern basin, whereas stations of Poseidon 234 (P234) are limited to the western Mediterranean Sea. During Urania MAI2 (Ura2) and Urania MAI7 (Ura7) only a few stations in the Adriatic 
Sea were sampled. In Fig. 3 the locations of stations with tracer measurements of all cruises are shown.

CFC-12 and $\mathrm{SF}_{6}$ samples were measured either directly on board or ashore from flame-sealed glass ampoules. The gas chromatographic instruments used for the analysis were similar to the ones described by Bullister and Weiss (1988), Bulsiewicz et al. (1998) and Vollmer and Weiss (2002). Precision for the CFC-12 measurements is $\pm 2 \%$ or $0.02 \mathrm{pmol} \mathrm{kg}^{-1}$, whichever is greater. Precision for the $\mathrm{SF}_{6}$ measurements is $1-2.5 \%$ (on board/cracker). For comparison with the tracers in the atmosphere, CFC-12 and $\mathrm{SF}_{6}$ concentrations (in pmol kg-1 and fmol kg-1, respectively) were converted into equivalent mixing ratios and are given in ppt.

Tritium was measured using the ${ }^{3} \mathrm{He}$ ingrowth method and is reported in tritium units (TU, 1 TU represents a $\left[{ }^{3} \mathrm{H}\right] /[\mathrm{H}]$ ratio of $10^{-18}$ ) (Clarke and Jenkins, 1976; Sültenfuß et al., 2009). Precision typically is $\pm 3 \%$ or 0.02 TU, whichever is greater, but partly lower for the 1987 data set (Roether et al., 1999).

For details about the methods, precision and accuracy, as well as for descriptions of the salinity, temperature and oxygen measurements, the reader is referred to the references in Table 1.

\subsection{Apparent tracer ages}

The CFC-12 apparent tracer ages were determined by direct comparison of the tracer concentrations in water with the atmospheric time history of the gas (Bullister, 2011), assuming $100 \%$ saturation in surface water.

The tritium- ${ }^{3} \mathrm{He}$ age is based on the radioactive decay of tritium into ${ }^{3} \mathrm{He}$. Assuming that no tritiugenic ${ }^{3} \mathrm{He}$ (from tritium decay) is present in surface waters, the tritium- ${ }^{3} \mathrm{He}$ age can be directly calculated, using the tritiugenic ${ }^{3} \mathrm{He}$ concentration in the water sample and the half-life of tritium. The tritiugenic ${ }^{3} \mathrm{He}$ in the water sample was determined by separation from the measured ${ }^{3} \mathrm{He}$ following the steps described by Roether et al. (2013a).

Any water sample represents a mixture of contributions that differ in their travel time from the formation region, and thus also in their tracer concentrations. The apparent tracer ages do not consider mixing, which explains the shift between tracer age and mean age, partly because the age information of water with zero tracer concentration (very old water) is lost. Furthermore, the tracer ages are biased depending on their specific non-linear atmospheric input functions. This means for example, the faster the growth rate (or decay rate), the younger is the tracer age (Waugh et al., 2003). The comparison of ages of the same tracer over time is biased by changes in growth rates. For CFC-12, for example, the atmospheric increase was rather exponential up to 1970 and then linear up to 1990 . Thereafter the growth rate decreased and after a period of almost no change (2000-2005), the concentrations are now slowly falling. The input function of tritium

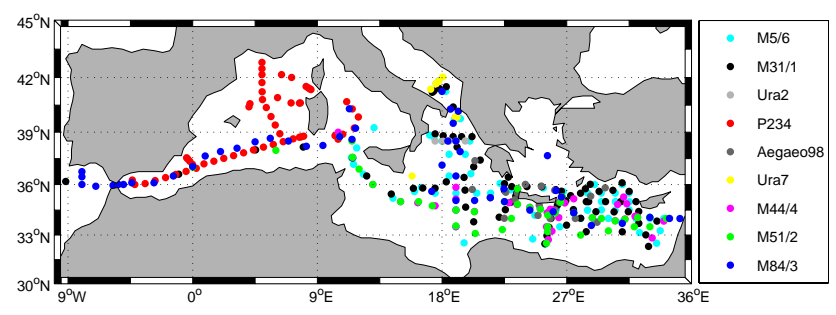

Fig. 3. The locations of all stations with tracer measurements of all cruises used in this work are shown: M5/6 in 1987, M31/1 in 1995, Ura2 in 1997, P234 in 1997, Aegaeo98 in 1998, Ura7 in 1999, M44/4 in 1999, M51/2 in 2001 and M84/3 in 2011.

shows a sharp peak in the 1960s (Fig. 2), which influences the tritium $-{ }^{3} \mathrm{He}$ ages, although they directly depend on the non-changing decay rate. Subsequent to the peak, the tritium concentrations decreased, largely due to its radioactive decay. The input functions of tritium and CFC-12, thus, are of a distinctly different shape (Fig. 2).

\subsection{The transit time distribution concept}

Mean ages of CFC-12, $\mathrm{SF}_{6}$ and tritium were determined using the transit time distribution (TTD) method (Hall and Plumb, 1994). The interior tracer concentration $c(t)$ is given by

$c(t)=\int_{0}^{\infty} c_{0}\left(t-t^{\prime}\right) \cdot e^{-\lambda t^{\prime}} \cdot G\left(t^{\prime}\right) \mathrm{d} t^{\prime}$,

where $c_{0}\left(t-t^{\prime}\right)$ is surface water tracer concentration, $e^{-\lambda t^{\prime}}$ is the radioactive decay term in case of tritium, with the decay constant $\lambda=0.05575$ and $G\left(t^{\prime}\right)$ is the transit time distribution. For steady transport an inverse Gaussian function is a good approximation for the TTD (Waugh et al., 2004):

$G\left(t^{\prime}\right)=\sqrt{\frac{\Gamma^{3}}{4 \pi \Delta^{2} t^{\prime 3}}} \cdot e^{\frac{-\Gamma\left(t^{\prime}-\Gamma^{2}\right.}{4 \Delta^{2} t^{\prime}}}$,

where $\Delta$ is the "width" of the TTD and $\Gamma$ is the mean age. Even though it has been shown that the shape of the TTD in the Mediterranean was different from a 1IG with $\Delta / \Gamma$ ratio of 1 in many places based on multiple-tracer analysis (Stöven and Tanhua, 2013), we chose a $\Delta / \Gamma$ ratio of 1 , as proposed by Waugh et al. (2004) for ocean interior waters, since we do not have enough tracer data to calculate a possible variability of the shape of the TTD over time. This simplification will bias the results to some degree, and we discuss this bias below.

The atmospheric time history of $\mathrm{SF}_{6}$ and $\mathrm{CFC}-12$ were taken from Bullister (2011). The input function of tritium originated from Roether et al. (1992) and was extended in time by R. Steinfeld (unpublished data). It was newly adjusted by Stöven and Tanhua (2013) using tritium 
Table 1. Summary of all cruises used in this work, showing dates, the sampling region and the respective references. EMed = eastern Mediterranean, WMed = western Mediterranean, NIonian = northern Ionian.

\begin{tabular}{|c|c|c|c|}
\hline Cruise & Date & Basin/Sea & Reference \\
\hline $\begin{array}{l}\text { Meteor } 5 / 6 \\
(\mathrm{M} 5 / 6)\end{array}$ & Aug/Sep 1987 & $\begin{array}{l}\text { EMed, Adriatic, } \\
\text { Cretan, } \\
\text { Tyrrhenian }\end{array}$ & $\begin{array}{l}\text { Nellen et al. (1996) } \\
\text { Schlitzer et al. (1991) (CFC12); } \\
\text { Roether and Schlitzer (1991) (CFC12, Tri) } \\
\text { Roether et al. (1999) (Tri) }\end{array}$ \\
\hline $\begin{array}{l}\text { Meteor 31/1 } \\
(\mathrm{M} 31 / 1)\end{array}$ & Jan/Feb 1995 & $\begin{array}{l}\text { EMed, Adriatic, Cretan, } \\
\text { (WMed) }\end{array}$ & $\begin{array}{l}\text { Hemleben et al. (1996) } \\
\text { Roether et al. (1996) (CFC12) } \\
\text { Roether et al. (1998a) (CFC12, Tri) }\end{array}$ \\
\hline $\begin{array}{l}\text { Urania MAI2 } \\
\text { (Ura2) }\end{array}$ & Aug/Sept 1997 & $\begin{array}{l}\text { Adriatic, } \\
\text { NIonian }\end{array}$ & $\begin{array}{l}\text { Manca et al. }(2002) \\
\text { Roether et al. }(1996,2007) \\
(\text { CFC12) }\end{array}$ \\
\hline $\begin{array}{l}\text { Poseidon } 234 \\
(\mathrm{P} 234)\end{array}$ & Oct/Nov 1997 & $\begin{array}{l}\text { WMed, } \\
\text { Tyrrhenian }\end{array}$ & $\begin{array}{l}\text { Rhein et al. (1999) (CFC12) } \\
\text { Roether and Lupton (2011) (Tri) }\end{array}$ \\
\hline $\begin{array}{l}\text { Aegaeo M4WF } \\
\text { (Aegaeo98) }\end{array}$ & Oct/Nov 1998 & Cretan, Levantine & Theocharis et al. (2002) (CFC12) \\
\hline $\begin{array}{l}\text { Urania MAI7 } \\
\text { (Ura7) }\end{array}$ & Feb 1999 & Adriatic & $\begin{array}{l}\text { Manca et al. (2002) } \\
\text { Roether et al. (2007) (CFC12) }\end{array}$ \\
\hline $\begin{array}{l}\text { Meteor 44/4 } \\
(\mathrm{M} 44 / 4)\end{array}$ & Apr/May 1999 & $\begin{array}{l}\text { EMed, } \\
\text { Tyrrhenian }\end{array}$ & $\begin{array}{l}\text { Pätzold et al. (2000) } \\
\text { Theocharis et al. (2002) (CFC12) } \\
\text { Roether and Lupton (2011) (Tri) }\end{array}$ \\
\hline $\begin{array}{l}\text { Meteor 51/2 } \\
(\mathrm{M} 51 / 2)\end{array}$ & Oct/Nov 2001 & $\begin{array}{l}\text { EMed, } \\
\text { Tyrrhenian, } \\
\text { (WMed) }\end{array}$ & $\begin{array}{l}\text { Hemleben et al. (2003) } \\
\text { Roether et al. (2007) (CFC12) } \\
\text { Schneider et al. (2010) (CFC12) } \\
\text { Roether and Lupton (2011) (Tri) }\end{array}$ \\
\hline $\begin{array}{l}\text { Meteor } 84 / 3 \\
(\mathrm{M} 84 / 3)\end{array}$ & Apr 2011 & $\begin{array}{l}\text { EMed, } \\
\text { Adriatic, } \\
\text { Tyrrhenian, } \\
\text { WMed }\end{array}$ & $\begin{array}{l}\left.\text { Stöven (2011) (CFC12, } \mathrm{SF}_{6}\right) \\
\left.\text { Stöven and Tanhua (2013) (CFC12, } \mathrm{SF}_{6}\right) \\
\text { Roether et al. (2013a) (Tri) }\end{array}$ \\
\hline
\end{tabular}

measurements in the Mediterranean Sea. This input function is almost identical to the one published by Roether et al. (2013a) derived from a slightly different approach. The tritium concentrations are generally $20 \%$ higher in the eastern Mediterranean as compared to the western Mediterranean Sea due to increased continental influence for the former (over land masses, tritium concentrations in the lower troposphere have been distinctly higher; Weiss and Roether, 1980).

Generally, the mean ages present a more realistic estimate for the real water age than the apparent tracer ages but they are dependent on our assumption of the shape of the TTD. This can bias the results in both directions depending if mixing was over- or underestimated or if mixing increased or decreased over time. The direction is the same for all tracers but the magnitude can differ. $\mathrm{SF}_{6}$ concentrations have increased rather steadily making it a good tracer for recent decades and probably also in the future. The usability of CFC- 12 is limited to older waters because of the almost non-changing atmospheric concentrations in the past $20 \mathrm{yr}$. A further uncertainty of the mean ages is the assumption of $100 \%$ saturation in surface waters of CFC-12 and $\mathrm{SF}_{6}$. Undersaturation is possible in areas where surface water quickly cools and subducts before equilibrium with the atmosphere is reached (e.g. in the deep water formation areas). The assumption of $100 \%$ saturation would then lead to an overestimation of the water age. For instance Tanhua et al. (2008) suggest that the saturation of $\mathrm{CFC}-12$ has increased over time as the atmospheric transient has decreased. Since we are analysing the temporal variability of ventilation ages of water masses, temporal variability of the surface saturation would lead to a bias in our analysis. We do not have sufficient information to realistically address this question for the Mediterranean but assume that the surface saturation has remained constant over the last decades, bearing in mind that a potential overestimation of ages (due to undersaturation) during intense convection periods could bias our analysis. 

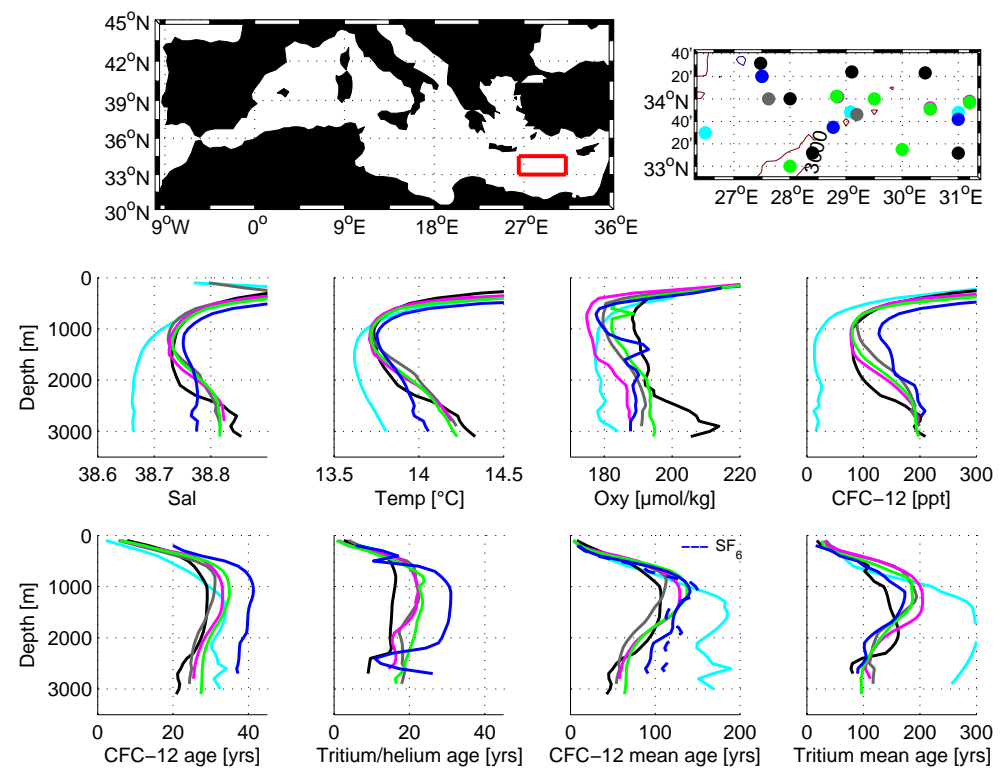

1987

$1995-1998$

$1999-2001-2011$

Fig. 4. The Levantine basin. In the upper left panel, a red box confines the respective area, where samples were taken on a map of the Mediterranean Sea. In the upper right panel, the exact locations of all sampled stations within this red box are shown. Each colour refers to one specific cruise/year specified in the legend. In the lower panels the same colours appear in the depth profiles of the measured parameters for each cruise. For the "mean-age panel", the mean-age calculated from $\mathrm{SF}_{6}$ is shown as a blue dashed line; only available for 2011 data.

\subsection{Combination and comparison of nine cruises}

In the past, changes in the ventilation of the Mediterranean Sea have been documented (e.g. EMT, WMT, see above). Now, with the tracer data from nine cruises over the last $25 \mathrm{yr}$ being available, a reasonable temporal and regional coverage has been obtained, which allows us to explore how those events are reflected in transient tracer data.

In the following we present and discuss tracer data and ages in nine areas in the Mediterranean Sea. As most of the campaigns focused on certain regions in the Mediterranean Sea, data from only three to seven cruises are available for the various areas. If more than one station during the same cruise falls into the boundaries of the chosen area, the mean profile is shown. The mean profile is calculated by first interpolating the individual profiles to standard depths using a piecewise cubic hermite interpolating method that do not allow too large vertical distances between data points, and then by taking the arithmetic mean of the interpolated profiles (e.g. Tanhua et al., 2010). The parameters are salinity, temperature, oxygen, $\mathrm{CFC}-12$, $\mathrm{CFC}-12$ age, tritium- ${ }^{3} \mathrm{He}$ age, CFC-12 mean age, tritium mean age, and for the cruise of 2011 also the $\mathrm{SF}_{6}$ mean age (mean ages means TTD-derived ages). A further instrument to identify changes in circulation is the comparison of $\mathrm{CFC}-12$ and $\mathrm{SF}_{6}$ ages determined in different years but at the same location. This approach (Tanhua et al., 2013) benefits from the almost identical atmospheric increase functions of both tracers with a time shift of $14 \mathrm{yr}$. In a steady-state situation, the tracer age of $\mathrm{SF}_{6}$ should match the tracer age of CFC-12 based on measurements taken $14 \mathrm{yr}$ earlier in the same region. Since we only have $\mathrm{SF}_{6}$ measurements for the cruise in 2011, the corresponding year for the CFC-12 measurements is 1997. For 6 regions the comparison of CFC-12 and $\mathrm{SF}_{6}$ tracer age profiles could be performed. In two cases we used CFC-12 measurements from 1998, which results in a time gap of only $13 \mathrm{yr}$. The atmospheric increase of CFC-12 up to the year 1990 was almost linear (Fig. 2). Thus, the bias created by the changing rate of increase is expected to be small.

In this work we focus on relative changes in concentrations and ages over a time period of up to $25 \mathrm{yr}$. This is the reason why we do not quantify the uncertainties, but only discuss biases affecting the relative comparison and not the absolute numbers. For a detailed discussion of the uncertainties of the cruise in the year 2011, see Stöven and Tanhua (2013).

\section{Results and interpretation}

The Levantine basin results are shown in Fig. 4 and those of the area south of Crete (north of the east Mediterranean ridge) in Fig. 5. We find similar profiles in the two areas. Prominent in all parameters is the cruise of 1987, which represents the pre-EMT situation (Figs. 4 and 5). The later cruises consistently show higher temperatures, salinity and tracer concentrations and lower mean ages below $1000 \mathrm{~m}$ depth, due to the extraordinary amount of rather young, warm and saline waters from the Aegean Sea added by the EMT. 

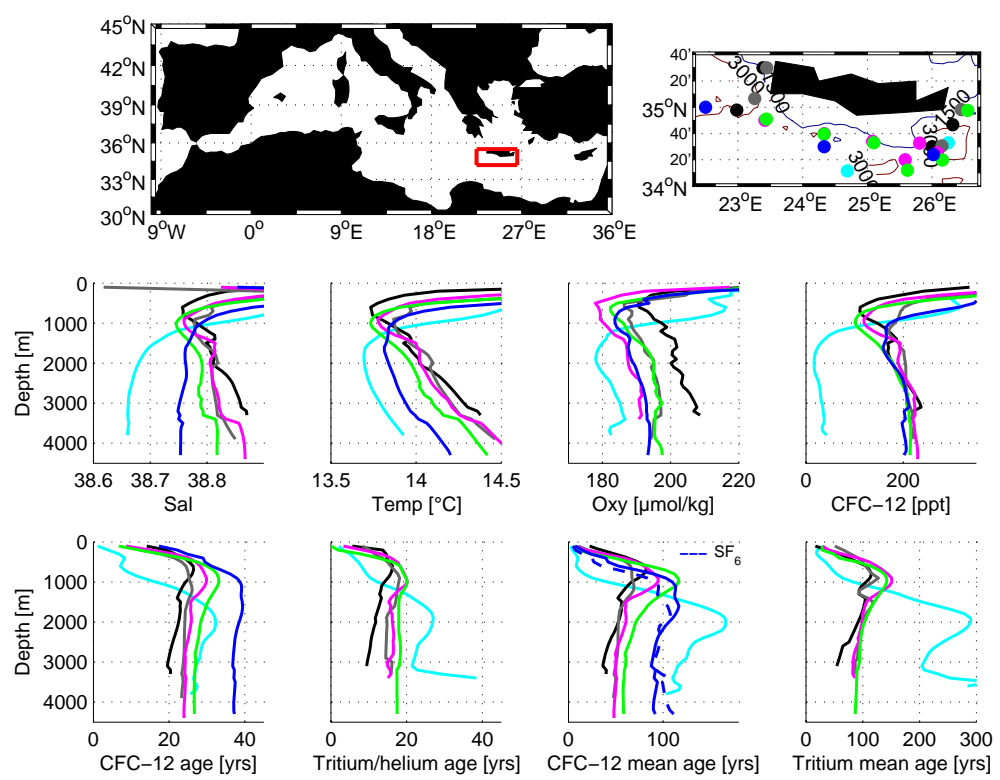

$1995-1998-2099-2011$

Fig. 5. Northern Levantine (south of Crete). For further explanation see caption of Fig. 4.

South of Crete, a gradual decrease in temperature and salinity is found after 1995. The oxygen profiles in the year 1995 also demonstrate the intrusion of new deep water with high concentrations, followed by a large drop in oxygen between 1995 and 1999, which has been attributed to enhanced oxygen consumption driven by large amounts of dissolved organic carbon (Klein et al., 2003).

In the CFC-12 profiles we also see a large difference between 1987 and 1995, whereas in the years after 1995 there is comparatively little change in CFC- 12 concentration between $1000 \mathrm{~m}$ and $2500 \mathrm{~m}$ and no change at all below $2500 \mathrm{~m}$ (Figs. 4 and 5). As the atmospheric CFC-12 concentrations had been increasing continuously, until the year 1995, a continuing increase in deep waters is expected also after 1995. The constant concentrations at depth point to a period of stagnation following the EMT, confirming the analysis of Roether et al. (2013b). At the same time, some change in temperature and salinity is visible, pointing to the admixture of water with similar tracer concentrations. Both scenarios must have led to increased water ages from 1995 to 2011 . If we look at the age profiles this is generally true (Figs. 4 and 5). Conspicuous is that the drop in the CFC-12 ages (and by trend also the tritium- ${ }^{3} \mathrm{He}$ ages) between 1987 and 1995 is less than one would expect, presumably as a result of the age biases mentioned in Sect. 2.2, due to the non-linearity of the input function and the changes in the growth rate of CFC12. We note that the TTD-based mean ages are much higher than the tracer ages and also closer to previous results (e.g., Roether and Schlitzer, 1991) that used a tracer constrained box model to estimate ventilation times. It thus appears that the tracer ages are rather a proxy of the real ages, but they

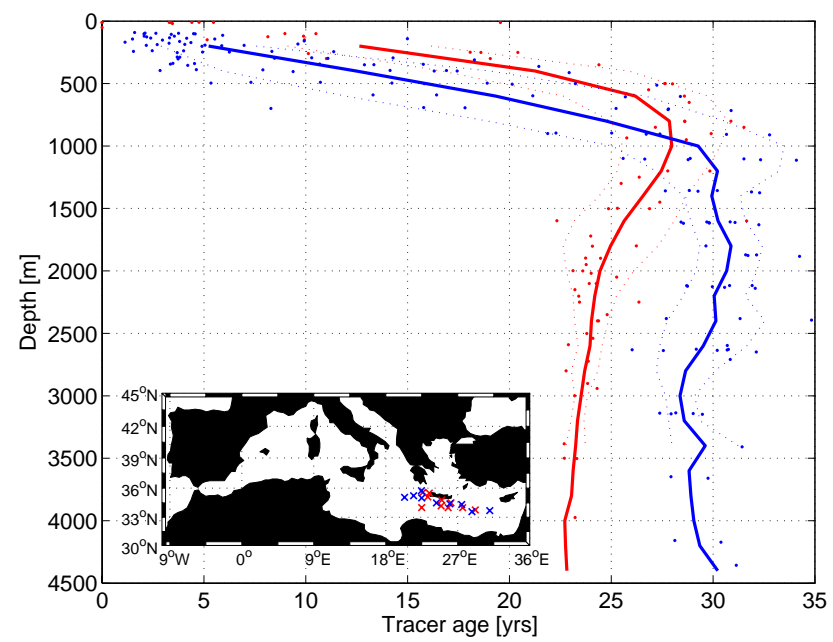

Fig. 6. The Levantine basin. CFC-12 and $\mathrm{SF}_{6}$ ages (dots) at the stations shown on the map plus the averaged profiles (lines) for the area. CFC-12 ages are shown in red for the year 1998 and $\mathrm{SF}_{6}$ ages in blue for the year 2011 .

certainly have a diagnostic potential. The fact that the tritium mean age generally is higher than the CFC-12 mean age is possibly due to the strongly peaked tritium input, for which a $\Delta / \Gamma$ ratio different to the value actually used might be more adequate. In fact, Stöven and Tanhua (2013) found a $\Delta / \Gamma$ ratio of 0.5 for that region. A noteworthy feature is that the CFC-12 and $\mathrm{SF}_{6}$ mean ages for 2011 agree rather well.

The uplift of water masses by the EMT can clearly be seen in all age profiles. The age maximum in Fig. 5 rises from $2000 \mathrm{~m}$ in 1987 to $800 \mathrm{~m}$ in 1995 . At the same time the 

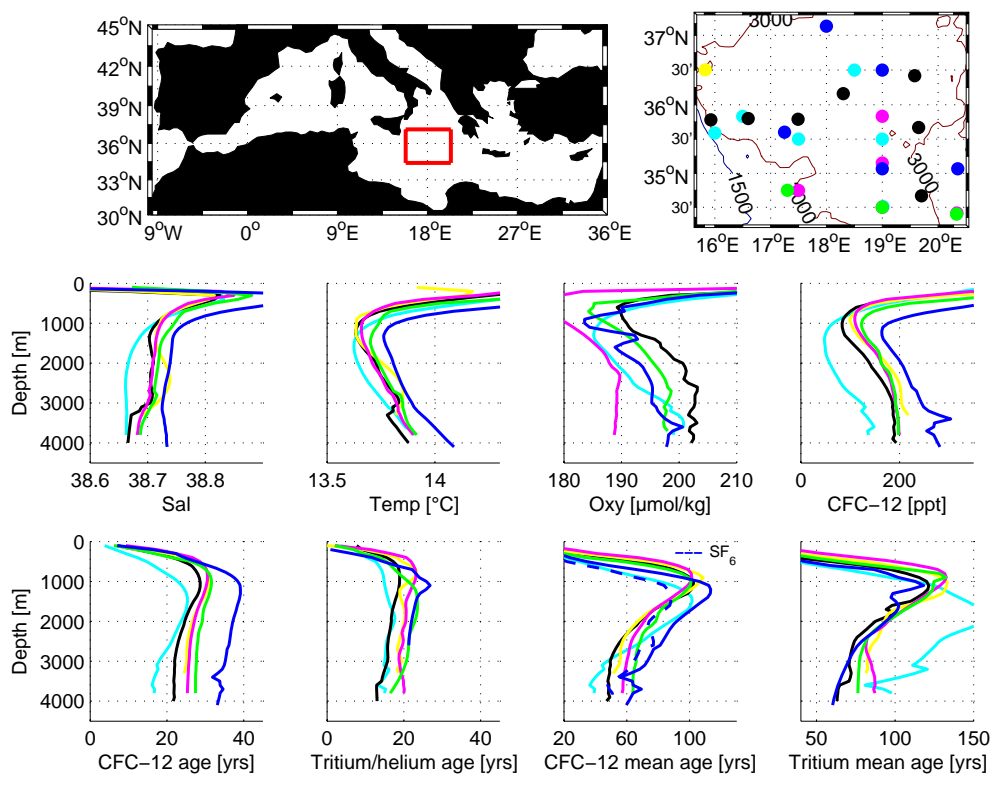

$1995 \longrightarrow 1999-1999-2001-2011$

Fig. 7. The central Ionian. For further explanation see caption of Fig. 4.

CFC-12 mean age decreases from $150 \mathrm{yr}$ to $80 \mathrm{yr}$, demonstrating the large amount of young water that has been transferred to depth during the EMT. In the course of time after 1995, the mean age and its centre depth increase again, perhaps moving slowly back to pre-EMT conditions.

Figure 6 displays the comparison of CFC-12 ages and of $\mathrm{SF}_{6}$ ages $13 \mathrm{yr}$ later for the Levantine basin. The 1998 profile represents the post-EMT situation with an uplifted age maximum at around $1000 \mathrm{~m}$. In the years up to 2011 (the "stagnation" phase at depth), the water below $1000 \mathrm{~m}$ became older (5-7 yr). In the intermediate layer down to $1000 \mathrm{~m}$, the shallower overturning circulation (LIW and CIW) reduces the age of the formerly uplifted old water, appearing as a vertical shift in the age gradient in the upper $1000 \mathrm{~m}$ of the water column.

The central Ionian is shown in Fig. 7. One notes that the parameter changes over time are less drastic than in the Levantine. The salinity and temperature profiles do not show any exceptional trends, while the enhanced oxygen consumption between 1995 and 1999 is even more pronounced than in the Levantine basin. The jump in the CFC-12 concentrations between 2001 and 2011 reflects the restarted deep-water supply from the Adriatic, after the mentioned "stagnation phase" (e.g. Manca et al., 2002). This is supported by the fact that a corresponding change is not yet apparent in the Levantine basin.

A further feature is noticeable in the profiles of the CFC-12 mean age in Fig. 7. In the year 1987 the young deep water is found at $3000-4000 \mathrm{~m}$. In the years 1995 to 2001 young water occupies a wider depth range from $2000-4000 \mathrm{~m}$ because of the large volumes of deep water of Aegean origin added by the EMT. This results in a more moderate vertical gradient in the mean age below $2000 \mathrm{~m}$. In 2011, the mean-age minimum is again found closer to the bottom, approaching the pre-EMT situation. The difference between the CFC-12 and the $\mathrm{SF}_{6}$ mean age in young waters can be explained by the different atmospheric histories. The almost constant concentrations of CFC-12 in the past $15 \mathrm{yr}$ led to no great age difference when areas get ventilated. The $\mathrm{SF}_{6}$ concentrations instead have increased continuously in the atmosphere and lead to younger mean ages in the same water mass. Another source of uncertainty in this analysis is the assumption of a $\Delta / \Gamma$ ratio of 1; Stöven and Tanhua (2013) have shown that this ratio was higher than 1 in the Adriatic overflow water during 2011. This would tend to bias our mean age estimates to be too low. However, the greatest difference between CFC12 and $\mathrm{SF}_{6}$ mean age in Fig. 7 is found between 1000 and $2000 \mathrm{~m}$ with water ages around $100 \mathrm{yr}$, whereas in the Levantine basin (Figs. 4 and 5) CFC-12 and $\mathrm{SF}_{6}$ mean age fit well at these depths and ages. This might be caused by mixing of (two) different water masses (old and young) in the Ionian basin, that cannot be resolved with a 1IG TTD.

Profiles in the two regions of deep water formation in the eastern Mediterranean, i.e., the Adriatic Sea as the "classical" formation area and the Aegean Sea as the "additional" one during the EMT, are shown in Figs. 8 and 9. The Adriatic Pit data in Fig. 8 also demonstrates the "stagnation phase" that started there after 1987, as already noted previously (e.g., Roether et al., 2007). The deep CFC-12 concentrations hardly change between 1987 and 1999, while the CFC-12 age increases. By 2011 the "normal" ventilation has restarted and temperature and especially salinity and CFC-12 have 

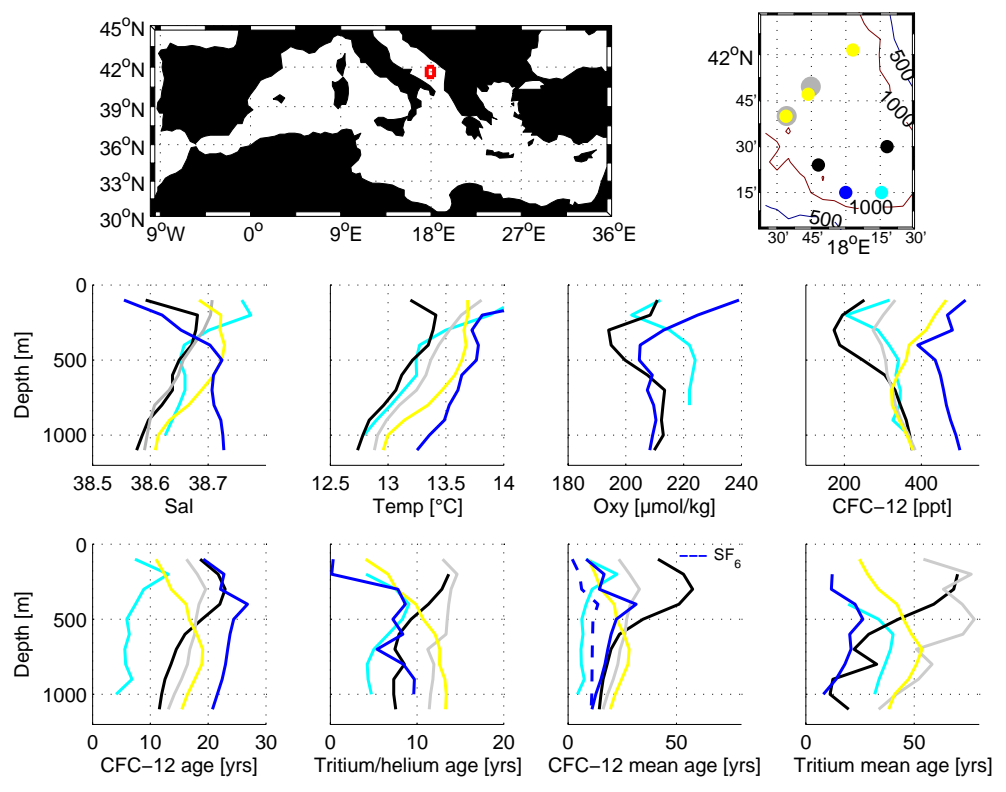

1987 1995 $1999-2011$

Fig. 8. The Adriatic Sea. For further explanation see caption of Fig. 4.
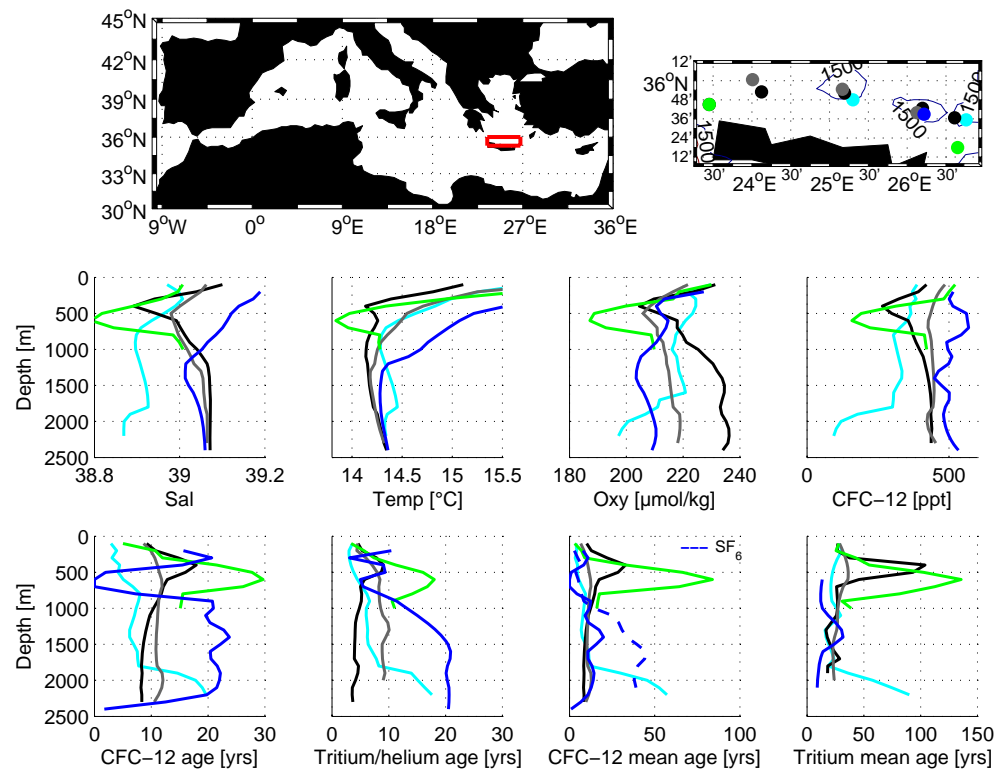

1987 $1995-1998$ $2001-2011$

Fig. 9. The Cretan Sea. For further explanation see caption of Fig. 4.

increased and the mean age has decreased. Again, in the CFC-12 tracer age profiles a significant decrease in tracer age is not apparent because of the almost non-changing atmospheric concentrations since 1995 . The tritium $-{ }^{3} \mathrm{He}$ age instead displays a very similar trend to the $\mathrm{CFC}-12$ and $\mathrm{SF}_{6}$ mean age. This demonstrates the utility of the tracer tritium for relatively young waters.

The Cretan Sea is a small basin in the southern Aegean Sea. It is characterized by variable and fast changing parameter values (Fig. 9). The water in the basin is generally very young $(<30 \mathrm{yr})$ and high in oxygen, similar to the Adriatic Sea. The layer between 200 and $900 \mathrm{~m}$ appears to be especially variable. In the years 1995 and 2001 old water masses, low in salinity, temperature and oxygen are found at these depths, whereas in 2011 the opposite trend is visible. Below $1800 \mathrm{~m}$ the pre-EMT water mass characteristics can clearly be recognized in all parameters. This depth was ventilated after 1987 and a more homogenized deep water mass 


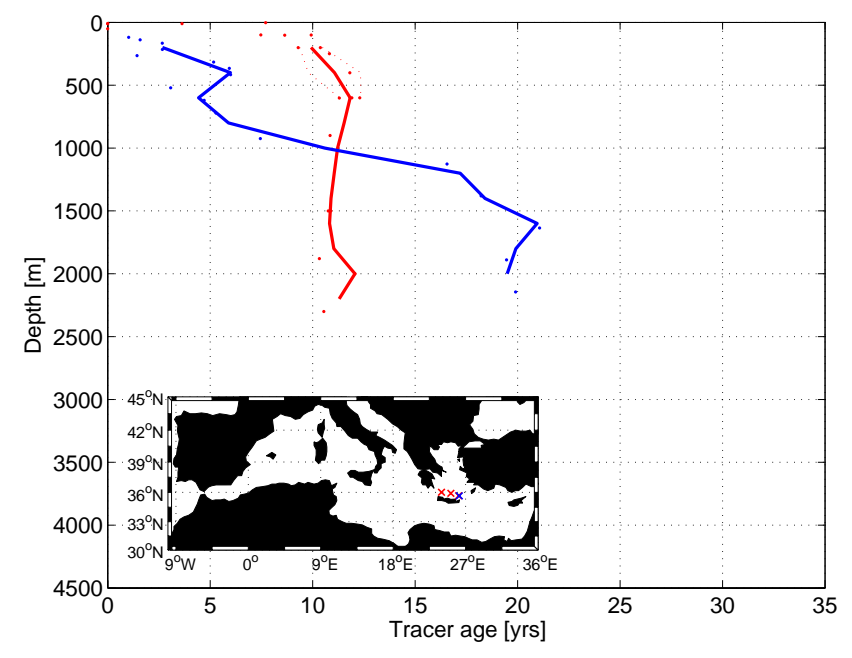

Fig. 10. The Cretan Sea. CFC-12 and $\mathrm{SF}_{6}$ ages (dots) at the stations shown on the map plus the averaged profiles (lines) for the area. CFC-12 ages are shown in red for the year 1998 and SF $_{6}$ ages in blue for the year 2011 .

was created, spanning from around 1200 down to the bottom. Again, for these young waters, which have not undergone a lot of mixing, the tritium ${ }^{3} \mathrm{He}$ age and the $\mathrm{SF}_{6}$ mean age show similar trends (increasing age at depth).

Figure 10 shows a well-mixed water column in the year 1998 for the Cretan Sea, with an age of around $11 \mathrm{yr}$. This is due to the intense deep water formation in the Aegean Sea in the early 90s, which ventilated the entire basin down to the bottom. By the year 2011 the restarted "normal" ventilation (formation of CIW, that reaches depth around 500$1200 \mathrm{~m}$ (Schlitzer et al., 1991)) has led to very young waters in the upper $1000 \mathrm{~m}$. In contrast, the water below $1000 \mathrm{~m}$ apparently has not been ventilated since then and aged by $10 \mathrm{yr}$. The Adriatic Sea circulation (Fig. 11) also seems to have come back to its pre-EMT conditions in the year 2011. The age gradient below $500 \mathrm{~m}$ that was apparent in 1998 disappeared due to the restarted deep water formation and the tracer age decreased by $\sim 7 \mathrm{yr}$.

In the following we discuss three regions in the western Mediterranean Sea: the Alboran Sea (Fig. 12), the south Liguro-Provençal basin (Fig. 13) and the southeast LiguroProvençal basin (Fig. 14). Concentrating first on the deep water (below $1500 \mathrm{~m}$ ), we can observe the same tendency in all three figures. Hardly changing salinities, temperatures and CFC-12 concentrations in the years 1995, 1997 and 2001, followed by a large increase by the year 2011. This feature is to be ascribed to the WMT, in which, similar to the EMT, increased water density led to exceptionally intense deep water formation and thus ventilation of the deep western basin (Schröder et al., 2006, 2008). These changes of hydrographic properties can potentially have significant impact on water mass properties and mixing in the North Atlantic, although they are outside the scope of this work. In this event that

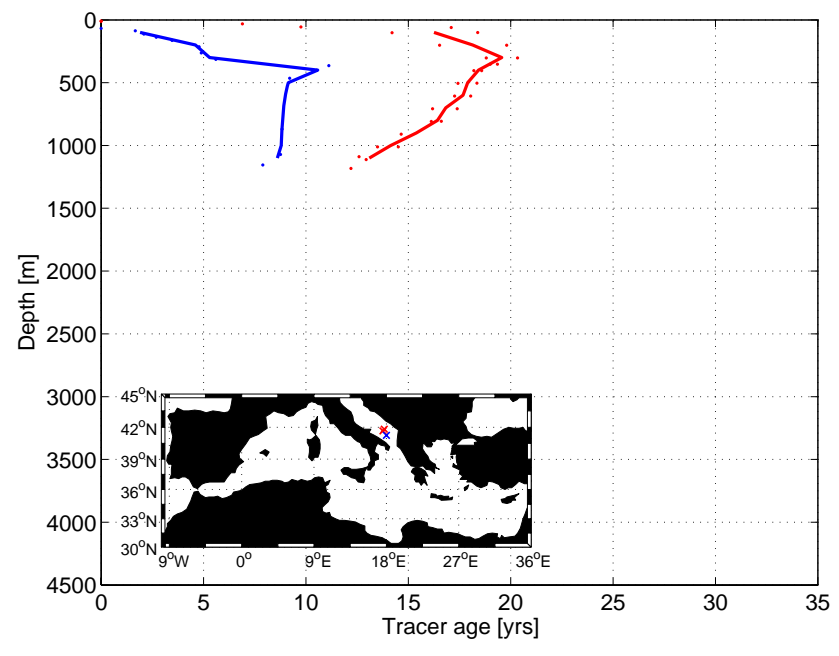

Fig. 11. The Adriatic Sea. CFC-12 and $\mathrm{SF}_{6}$ ages (dots) at the stations shown on the map plus the averaged profiles (lines) for the area. CFC-12 ages are shown in red for the year 1997 and SF $_{6}$ ages in blue for the year 2011 .

began about ten years after the EMT, the above-mentioned shortcomings of the tracer ages compared to the mean ages as well as the limits of the tracer CFC-12 itself become clear. The expected decrease in water age due to the recent significant ventilation of the deep water is neither seen in the CFC-12 ages, nor in the tritium- ${ }^{3} \mathrm{He}$ ages and the CFC- 12 mean ages. The tracer ages do not take mixing into account, which biases the results the more, the older a water mass is. In the Adriatic Sea (Fig. 8), where the tracer age at depth is only around $10 \mathrm{yr}$, the tritium- ${ }^{3} \mathrm{He}$ age is similar to the $\mathrm{SF}_{6}$ mean age, but here in the central western basin the water is older and tracer age and mean age do not match anymore. The CFC-12 ages are additionally biased because deep water ventilated between 2001 and 2011 was exposed to nearly constant or even decreasing atmospheric concentrations. This also influenced the CFC-12 mean age in 2011, although that bias is less strong: the CFC-12 mean age in Fig. 13 shows a continuous aging of the deep water mass from 1995 to 2001 while in 2011 the CFC-12 mean age decreased slightly. The CFC-12 concentration on the other hand, shows a marked increase between 2001 and 2011; a tell-tale of the WMT. The signal in the $\mathrm{SF}_{6}$ mean age is more pronounced, in particular close to the bottom. The tritium mean age shows the same trend, but in general we think that the $\mathrm{SF}_{6}$ mean age is more robust because the tritium input function is on the one hand so strongly peaked and on the other hand regional differences (e.g. increased tritium inputs in the deep water formation areas due to the vicinity to the continent) would probably change the tritium mean age substantially. However, Stöven and Tanhua (2013) found a 2IG distribution for the western Mediterranean Sea with $60 \%$ old water and $40 \%$ very young water, which would change our results of the mean ages of all tracers. Similar to the accelerated oxygen consumption in the 

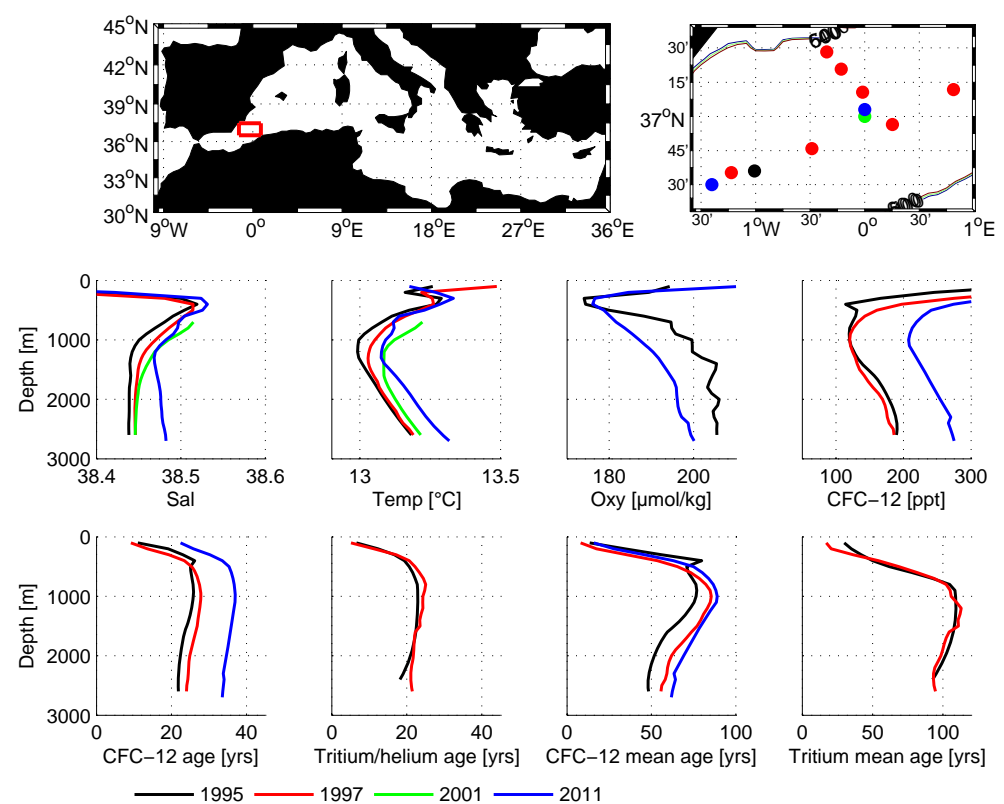

1995 $-2097-2011$

Fig. 12. The Alboran Sea. For further explanation see caption of Fig. 4.
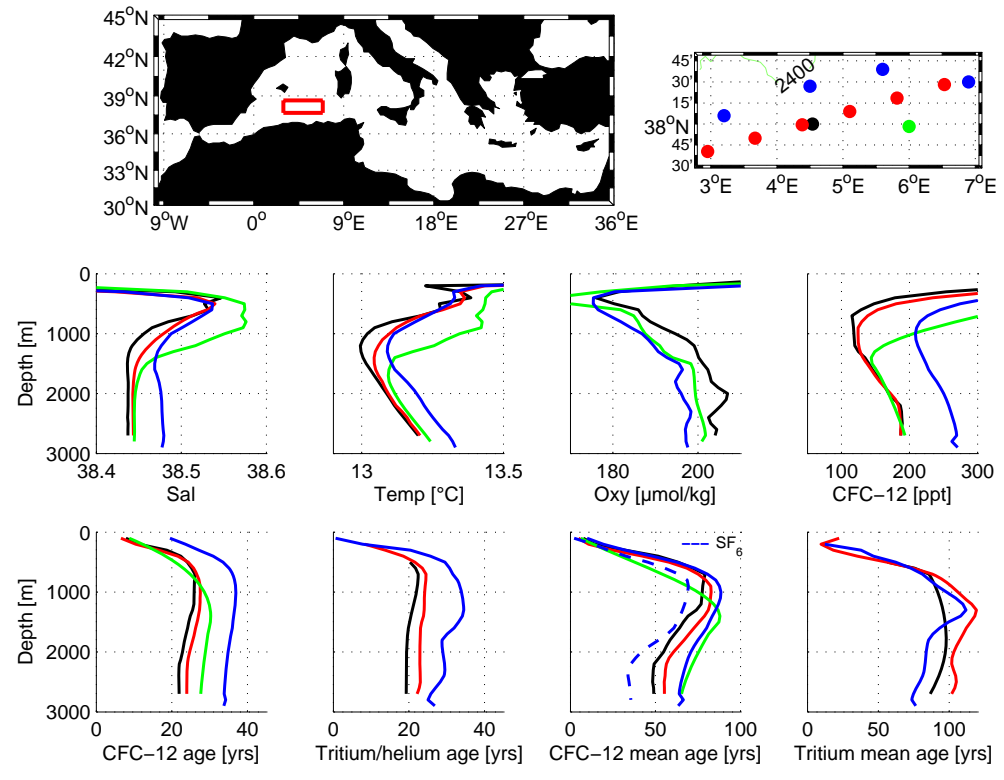

Fig. 13. The south Liguro-Provençal basin. For further explanation see caption of Fig. 4.

eastern basin after the EMT, we find low oxygen concentrations in the year 2011, which leads to the tentative conclusion that the WMT was also followed by increased consumption. However, an uplift of isolines is not obvious. Furthermore, the parameter profiles between 500 and $1500 \mathrm{~m}$ in the year 2001 (Fig. 13) suggest that the impact of the EMT (warmer and more saline water) had already reached the western basin in that year, influencing the entire intermediate layer.
The influence of the WMT in the Liguro-Provençal basin is also visible in Fig. 15, where the tracer age at depth decreased by about $5 \mathrm{yr}$ in the period from 1997 to 2011. Furthermore, the entire water column shows a moderate age decrease, which in the intermediate waters could be an effect of the EMT. The western part of the Alboran Sea (Fig. 16) is the only basin where we find almost unchanged tracer age profiles, which suggest a steady circulation at least in the upper 

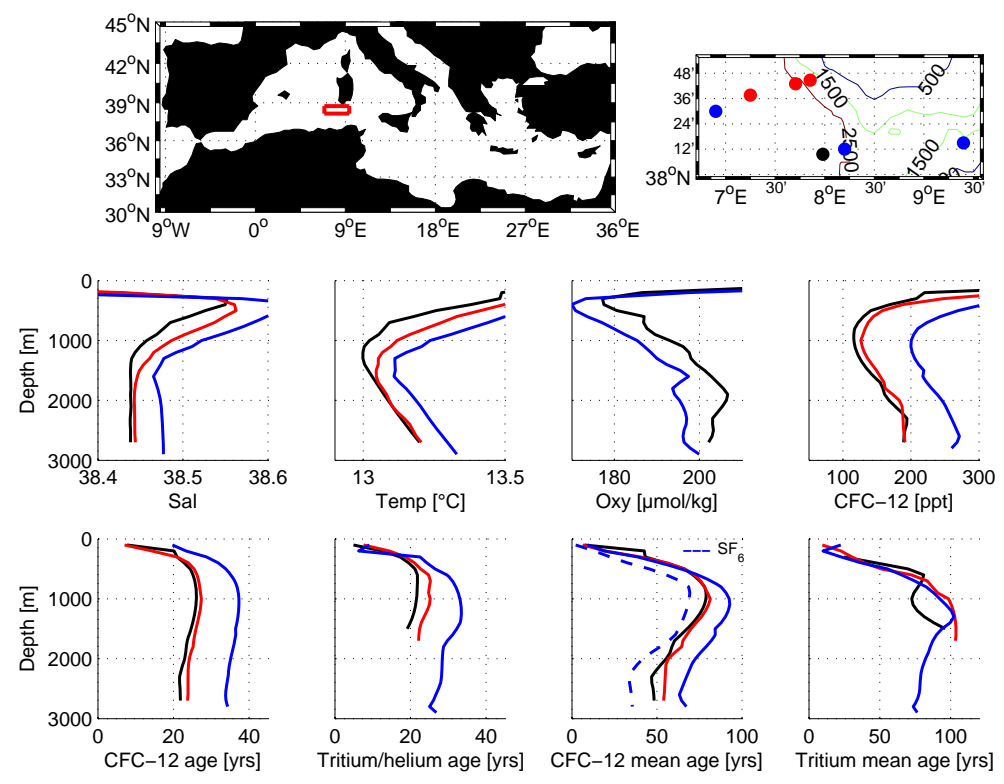

Fig. 14. The southeast Liguro-Provençal basin. For further explanation see caption of Fig. 4.

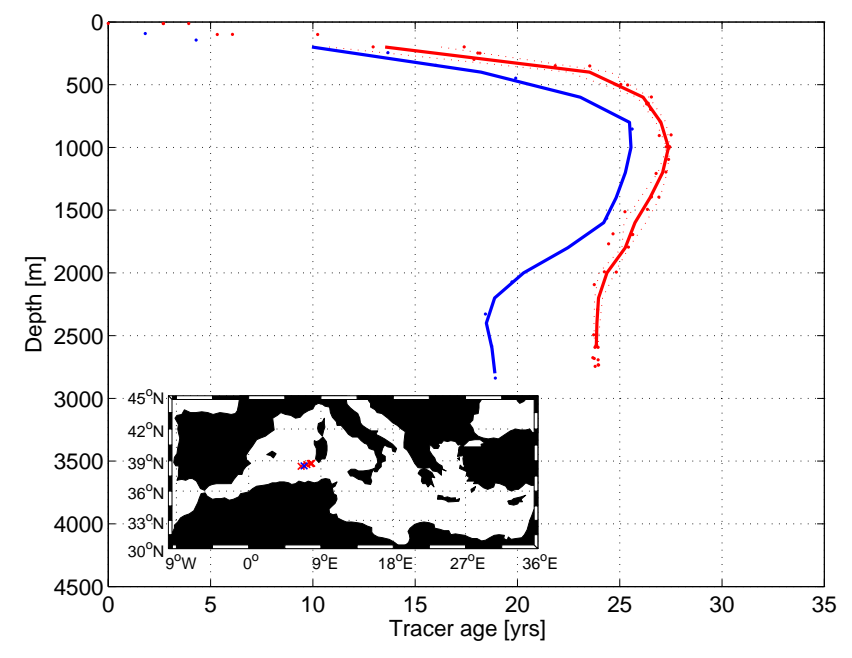

Fig. 15. The southeast Liguro-Provençal basin. $\mathrm{CFC}-12$ and $\mathrm{SF}_{6}$ ages (dots) at the stations shown on the map plus the averaged profiles (lines) for the area. CFC-12 ages are shown in red for the year 1997 and $\mathrm{SF}_{6}$ ages in blue for the year 2011.

$800 \mathrm{~m}$. Below that depth, the influence of the WMT might be visible by younger water in 2011.

Figure 17 shows the situation in the Tyrrhenian Sea, a basin where Western Mediterranean Deep Water mixes with the overflow waters of the Sicily Channel (LIW, CIW and tEMDW). There was EMT-induced enhanced mixing in the 1990 s, but this involved rather old waters from the eastern basin (Roether and Lupton, 2011), so that insignificant changes in ventilation are apparent after 1987, keeping the deep water mean ages around $100 \mathrm{yr}$. The 1987 profiles,

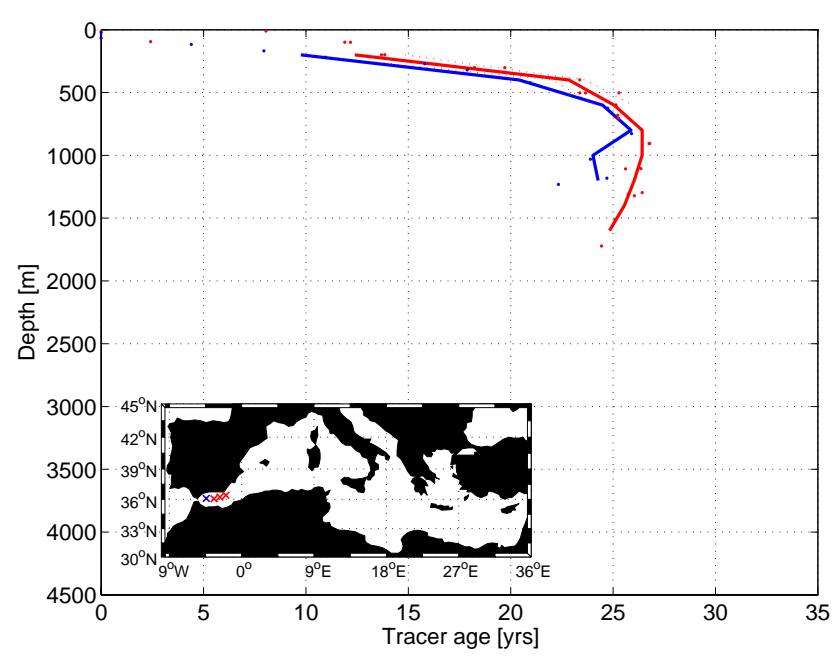

Fig. 16. The Alboran Sea. CFC-12 and $\mathrm{SF}_{6}$ ages (dots) at the stations shown on the map plus the averaged profiles (lines) for the area. CFC-12 ages are shown in red for the year 1997 and $\mathrm{SF}_{6}$ ages in blue for the year 2011 .

being not yet affected by the EMT, slightly differ from the later ones. The signal of the WMT had not reached the basin even by 2011 , when below $2500 \mathrm{~m}$, an old water mass was still found in that same year. This can also be seen in Fig. 18, where water ages increase below $1800 \mathrm{~m}$. Furthermore, we find a significant decrease in age of up to $20 \mathrm{yr}$ between 500 and $1500 \mathrm{~m}$. This layer is fed by the input of water over the Sicily Channel $(\sim 500 \mathrm{~m})$ from the east. Since the EMT led to upwelling of old water reaching up into the LIW, the signal in the intermediate layer in the Tyrrhenian Sea in 1997 most 

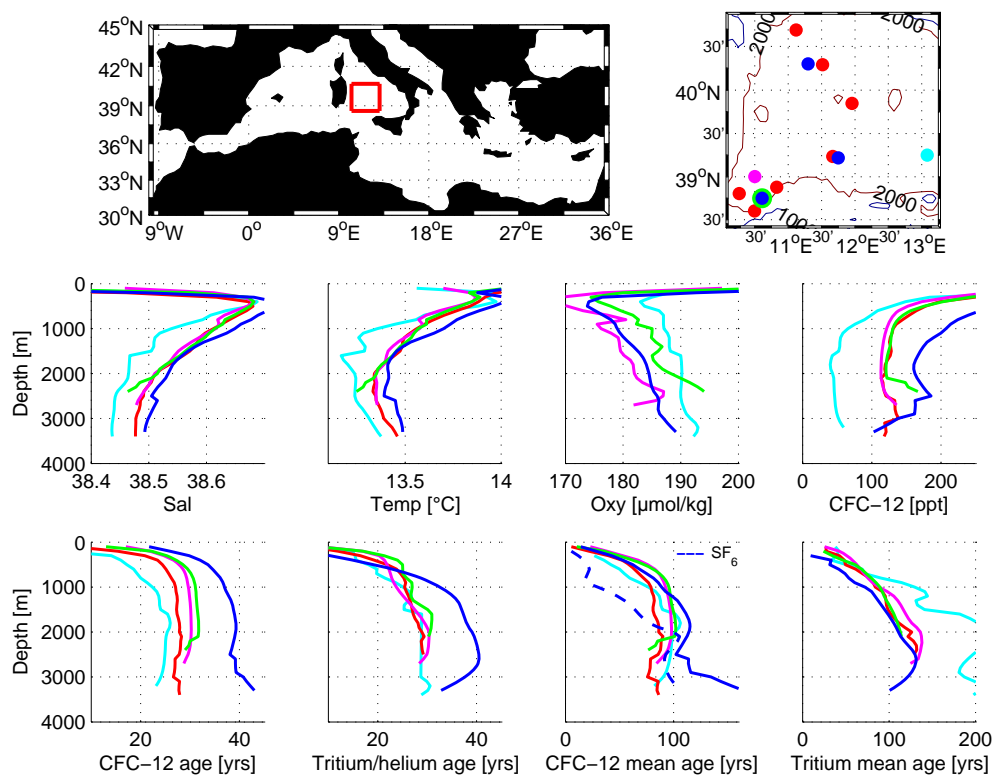
$1997-2099-2001-2011$

Fig. 17. The Tyrrhenian Sea. For further explanation see caption of Fig. 4.

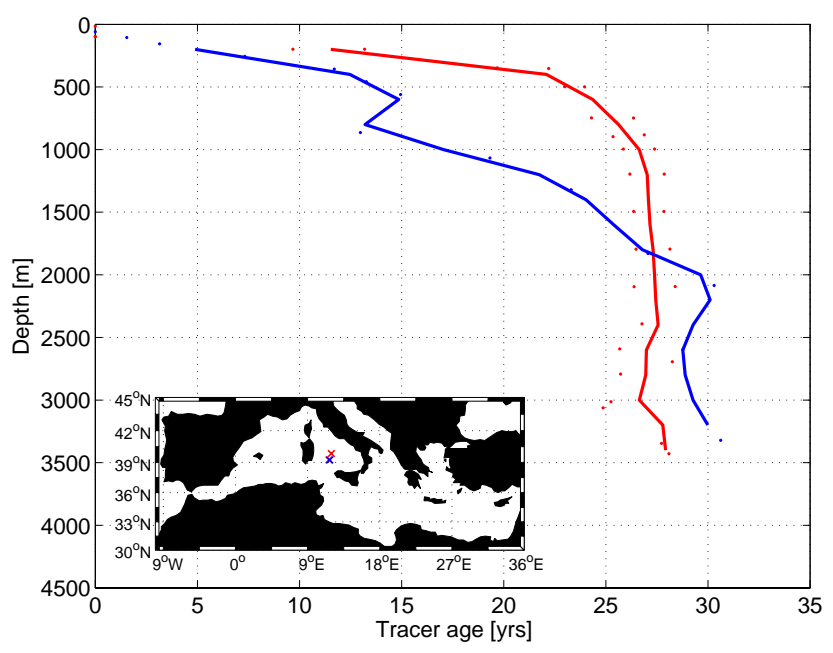

Fig. 18. The Tyrrhenian Sea. $\mathrm{CFC}-12$ and $\mathrm{SF}_{6}$ ages (dots) at the stations shown on the map plus the averaged profiles (lines) for the area. CFC-12 ages are shown in red for the year 1997 and $\mathrm{SF}_{6}$ ages in blue for the year 2011.

probably is influenced by this older water. By 2011, the "normal" circulation/ventilation of the LIW was restored, which led to a decrease in age compared to 1997.

\section{Conclusions}

This study analyses a large data set of several transient tracers over a period of $25 \mathrm{yr}$ in the Mediterranean Sea, from which we deduced an overview of ventilation and its temporal changes throughout the sea. The tracer data were used to obtain water mass ages, using different methods and assumptions, and regional as well as temporal comparisons were carried out. Furthermore, the different methods to estimate the ages were tested for applicability to the Mediterranean Sea.

The two dominating events that changed the ventilation, namely the Eastern Mediterranean Transient (EMT) in the eastern basin, and the Western Mediterranean Transition (WMT) in the western basin around $12-15 \mathrm{yr}$ later can clearly be recognized in most parameters. The EMT led to an uplift of parameter isolines in consequence of its considerable addition of new deep water of Aegean origin, which was followed by a "stagnation phase" with respect to ventilation. Our analysis indicates a return toward pre-EMT conditions after 2001 with a restart of the classical Adriatic deep water source, a deepening of the isolines and recent ventilation of the Ionian deep waters. In the Levantine basin, in contrast, we see no signs of recent ventilation of the deep water since the EMT in the early 1990s. The signal of the EMT (e.g., high salinities and temperatures) propagated west, reaching the Tyrrhenian basin before 1997 and the intermediate depths of the western basin between 1997 and 2001, acting as a triggering factor of the WMT beginning in 2004/2005. Differently from the eastern basin, the data in the western basin do not show an uplift of isolines in consequence of the WMT. While by the year 2011 the signal of the WMT was visible in the entire western basin, it had yet not reached the Tyrrhenian Sea.

The main results concerning the age calculation methods used in this work are the following: apparent tracer ages, that is, the period between the sampling and the point back 
in time when the atmospheric tracer concentration was the same as the measured value, is a useful diagnostic but only a proxy of the real age. A better estimate of the real age is the mean age obtained using the TTD (transit time distribution) method. However, the ages obtained by both these methods vary between the different tracers. For the TTD-based ages this arises mainly from an inadequate choice of the strength of mixing and the fact that the Mediterranean Sea circulation is not in steady-state and for the tracer ages from its dependence on the specific input history and the fact that mixing is not considered. Particularly we want to point out the difficulties in estimating changes in age over time with apparent tracer ages. Ages can be biased in different directions and with different magnitude, when comparing tracer ages of the same tracer for different time periods. Time invariant tracer ages do not imply constant ventilation and vice versa. In the case of CFC-12, for example, the apparent tracer age underestimates the age prior to about 1970, when the atmospheric concentration increased almost exponentially, and overestimated it, since about the year 2000 when the atmospheric concentrations hardly changed or even decreased. The dependence on the input histories is particularly problematic if one deals with a transient situation such as that caused by the EMT or the WMT. The apparent tracer ages are most strongly affected, but an effect is also visible in the mean ages. We find that for recently ventilated waters $\mathrm{SF}_{6}$-based ages are particularly realistic due to its smooth input history (Fig. 2). Tritium is problematic due to uncertainties of the tritium input function. That input varies also regionally depending on vicinity to land masses, and moreover, it strongly decreased in recent decades, so that the internal recirculation became dominant relative to new input. A special approach to identify temporal changes in ventilation was done by a comparison of apparent CFC-12 ages vs. $\mathrm{SF}_{6}$ ages obtained $14 \mathrm{yr}$ later, when the growth rate of the $\mathrm{SF}_{6}$ input from the atmosphere was very similar to that of CFC-12 at the earlier time. Generally, the results of the other parameter comparisons were confirmed and also that the Mediterranean Sea is clearly not in a steady state. The only basin with almost no changes in ventilation ages was the Alboran Sea, which is close to the Strait of Gibraltar and mainly influenced by the Atlantic Ocean. However, the changes in salinity observed in the Alboran Sea can potentially have far reaching influence on North Atlantic water mass properties.

Basically, the TTD method assumes circulation/ventilation to be in a steady state, which makes evaluation of the unsteady ventilation in the Mediterranean a challenge. A more detailed analysis of the contemporary Mediterranean TTD has been made by Stöven and Tanhua (2013) for observations obtained from the Meteor cruise of 2011 using the tracers CFC-12, tritium and $\mathrm{SF}_{6}$.
Acknowledgements. We sincerely acknowledge the work of all scientists and crews on the research cruises and helpers in the home laboratories who contributed to tracer sampling and measurements in the Mediterranean Sea since 1987. We acknowledge a grant from the German Science Foundation (DFG) TA3173/3 that supported A. Schneider during preparation of this manuscript, part of the publication costs and helium/tritium measurements.

The service charges for this open access publication have been covered by a Research Centre of the Helmholtz Association.

Edited by: M. Hoppema

\section{References}

Astraldi, M., Gasparini, G., Sparnocchia, S., Moretti, M., and Sansone, E.: The characteristics of the water masses and the water transport in the Sicily Strait at long time scales, in Dynamics of Mediterranean straits and channels, Bulletin de l'Institut Océanographique, edited by: Briand, F., 17, 95-115, 1996.

Bergamasco, A. and Malanotte-Rizzoli, P.: The circulation of the Mediterranean Sea: a historical review of experimental investigations, Adv. Oceanogr. Limnol., 1, 11-28, doi:10.1080/19475721.2010.491656, 2010.

Bullister, J. L.: Atmospheric CFC-11, CFC-12, CFC-113, $\mathrm{CCl}_{4}$ and $\mathrm{SF}_{6}$ Histories (1910-2011), Carbon Dioxide Information Analysis Center, available at: http://cdiac.ornl.gov/oceans/new_ atmCFC.html (last access: March 2012), 2011.

Bullister, J. and Weiss, R.: Determination of $\mathrm{CCL}_{3} \mathrm{~F}$ and $\mathrm{CCL}_{2} \mathrm{~F}_{2}$ in Seawater and Air, Deep Sea Res.-Pt. A, 35, 839-853, doi:10.1016/0198-0149(88)90033-7, 1988.

Bulsiewicz, K., Rose, H., Klatt, O., Putzka, A., and Roether, W.: A capillary-column chromatographic system for efficient chlorofluorocarbon measurements in ocean waters, J. Geophys. Res., 103, 15959-15970, 1998.

Clarke, W. and Jenkins, W.: Determination of Tritium by MassSpectrometric Measurement of ${ }^{3} \mathrm{He}$, Int. J. Applied Ra., 27, 515522, doi:10.1016/0020-708X(76)90082-X, 1976.

Gascard, J.-C.: Mediterranean deepwater formation, baroclinic instability and oceanic eddies, Oceanol. Acta, 1, 315-330, 1978.

Gasparini, G. P., Ortona, A., Budillon, G., Astraldi, M., and Sansone, E.: The effect of the Eastern Mediterranean Transient on the hydrographic characteristics in the Strait of Sicily and in the Tyrrhenian Sea, Deep Sea Res.-Pt. I, 52, 915-935, doi:10.1016/j.dsr.2005.01.001, 2005.

Hall, T. M. and Plumb, R. A.: Age as a diagnostic of stratospheric transport, J. Geophys. Res., 99, 1059-1070, 1994.

Hemleben, C., Roether, W., and Stoffers, P.: Östliches Mittelmeer, Rotes Meer, Arabisches Meer, Cruise No. 31, 30 December 1994-22 March 1995, METEOR-Berichte, Universität Hamburg, 1996.

Hemleben, C., Hoernle, K., Jørgensen, B. B., and Roether, W.: Ostatlantik, Mittelmeer, Schwarzes Meer, Cruise No. 51, 12 September-28 December 2001, METEOR-Berichte, Universität Hamburg., 2003.

Klein, B., Roether, W., Kress, N., Manca, B. B., D’Alcala, M. R., Souvermezoglou, E., Theocharis, A., Civitarese, G., and Luchetta, A.: Accelerated oxygen consumption in east- 
ern Mediterranean deep waters following the recent changes in thermohaline circulation, J. Geophys. Res., 108, 8107, doi:10.1029/2002JC001454, 2003.

Lascaratos, A., Roether, W., Nittis, K., and Klein, B.: Recent changes in deep water formation and spreading in the eastern Mediterranean Sea: a review, Prog. Oceanogr., 44, 5-36, doi:10.1016/S0079-6611(99)00019-1, 1999.

Leaman, K. D. and Schott, F. A.: Hydrographic structure of the convection regime in the Gulf of Lions: Winter 1987, J. Phys. Oceanogr., 21, 575-598, doi:10.1175/15200485(1991)021<0575:HSOTCR>2.0.CO;2, 1991.

Malanotte-Rizzoli, P. and Hecht, A.: Large-scale properties of the Eastern Mediterranean?: a review, Oceanol. Acta, 11, 323-335, 1988.

Manca, B. B., Kovačević, V., Gačić, M., and Viezzoli, D.: Dense water formation in the Southern Adriatic Sea and spreading into the Ionian Sea in the period 1997-1999, J. Marine Syst., 34, 133154, 2002.

MEDOC Group: Observation of formation of deep water in the Mediterranean Sea, 1969, Nature, 227, 1037-1040, 1970.

Millot, C.: Circulation in the Western Mediterranean Sea, J. Marine Syst., 20, 423-442, doi:10.1016/S0924-7963(98)00078-5, 1999.

Nellen, W., Bettac, W., Roether, W., Schnack, D., Thiel, H., Weikert, H., and Zeitschel, B.: MINDIK, Reise Nr. 5, 2 January-24 September 1987, Meteor-Berichte Universität Hamburg., 1996.

Pinardi, N. and Masetti, E.: Variability of the large scale general circulation of the Mediterranean Sea from observations and modelling: a review, Palaeogeogr. Palaeocl., 158, 153-173, doi:10.1016/S0031-0182(00)00048-1, 2000.

Pätzold, J., Halbach, P. E., Hempel, G., and Weikert, H.: Östliches Mittelmeer - Nördliches Rotes Meer, Cruise No. 44, 22 January16 May 1999, METEOR-Berichte, Universität Hamburg, 2000.

Rhein, M., Send, U., Klein, B., and Krahmann, G.: Interbasin deep water exchange in the western Mediterranean, J. Geophys. Res., 104, 495-508, doi:10.1029/1999JC900162, 1999.

Roether, W. and Lupton, J. E.: Tracers confirm downward mixing of Tyrrhenian Sea upper waters associated with the Eastern Mediterranean Transient, Ocean Sci., 7, 91-99, doi:10.5194/os7-91-2011, 2011.

Roether, W. and Schlitzer, R.: Eastern Mediterranean deep water renewal on the basis of chlorofluoromethane and tritium data, Dynam. Atmos. Oceans, 15, 333-354, doi:10.1016/03770265(91)90025-B, 1991.

Roether, W., Schlosser, P., Kuntz, R., and Weiss, W.: Transienttracer studies of the thermohaline circulation of the Mediterranean, in Winds and Currents of the Mediterranean Basin, Proc. NATO workshop "Atmospheric and Oceanic Circulations in the Mediterranean Basin", 7-14 September 1983, 291-317, H. Charnock, Harvard University, Cambridge MA, 1992.

Roether, W., Manca, B. B., Klein, B., Bregant, D., Georgopoulos, D., Beitzel, V., Kovacevic, V., and Luchetta, A.: Recent changes in Eastern Mediterranean Deep Waters, Science, 271, 333-335, 1996.

Roether, W., Klein, B., Beitzel, V., and Manca, B. B.: Property distributions and transient-tracer ages in Levantine Intermediate Water in the Eastern Mediterranean, J. Marine Syst., 18, 71-87, doi:10.1016/S0924-7963(98)00006-2, 1998a.
Roether, W., Well, R., Putzka, A., and Rüth, C.: Component separation of oceanic helium, J. Geophys. Res., 103, 27931, doi:10.1029/98JC02234, 1998b.

Roether, W., Beitzel, V., Sültenfuß, J., and Putzka, A.: The Eastern Mediterranean tritium distribution in 1987, J. Marine Syst., 20, 49-61, doi:10.1016/S0924-7963(98)00070-0, 1999.

Roether, W., Klein, B., Manca, B., Theocharis, A., and Kioroglou, S.: Transient Eastern Mediterranean deep waters in response to the massive dense-water output of the Aegean Sea in the 1990s, Prog. Oceanogr., 74, 540-571, doi:10.1016/j.pocean.2007.03.001, 2007.

Roether, W., Jean-Baptiste, P., Fourré, E., and Sültenfuß, J.: The transient distributions of nuclear weapon-generated tritium and its decay product ${ }^{3} \mathrm{He}$ in the Mediterranean Sea, 1952-2011, and their oceanographic potential, Ocean Sci., 9, 837-854, doi:10.5194/os-9-837-2013, 2013a.

Roether, W., Klein, B., and Hainbucher, D.: The Eastern Mediterranean Transient: Evidence for similar events previously?, in AGU Monograph "The Mediterranean Sea: Temporal Variability and Spatial Patterns”, edited by: Eusebi-Borzelli, G.-L., 2013b.

Schlitzer, R., Roether, W., Oster, H., Junghans, H.-G., Hausmann, M., Johannsen, H., and Michelato, A.: Chlorofluoromethane and oxygen in the Eastern Mediterranean, Deep Sea Res.-Pt. A, 38, 1531-1551, doi:10.1016/0198-0149(91)90088-W, 1991.

Schneider, A., Tanhua, T., Körtzinger, A., and Wallace, D. W. R.: High anthropogenic carbon content in the eastern Mediterranean, J. Geophys. Res., 115, C12050, doi:10.1029/2010JC006171, 2010.

Schröder, K., Gasparini, G. P., Tangherlini, M., and Astraldi, M.: Deep and intermediate water in the western Mediterranean under the influence of the Eastern Mediterranean Transient, Geophys. Res. Lett., 33, L21607, doi:10.1029/2006GL027121, 2006.

Schröder, K., Ribotti, A., Borghini, M., Sorgente, R., Perilli, A., and Gasparini, G. P.: An extensive western Mediterranean deep water renewal between 2004 and 2006, Geophys. Res. Lett., 35, L18605, doi:10.1029/2008GL035146, 2008.

Sonnerup, R. E.: On the relations among CFC derived water mass ages, Geophys. Res. Lett., 28, 1739-1742, doi:10.1029/2000GL012569, 2001.

Sparnocchia, S., Gasparini, G., Astraldi, M., Borghini, M., and Pistek, P.: Dynamics and mixing of the Eastern Mediterranean outflow in the Tyrrhenian basin, J. Marine Syst., 20, 301-317, doi:10.1016/S0924-7963(98)00088-8, 1999.

Stratford, K. and Williams, R. G.: A tracer study of the formation, dispersal and renewal of Levantine Intermediate Water, J. Geophys. Res.-Oceans, 102, 12539-12549, doi:10.1029/97JC00019, 1997.

Stratford, K., Williams, R. G., and Drakopoulos, P. G.: Estimating climatological age from a model-derived oxygen-age relationship in the Mediterranean, J. Marine Syst., 18, 215-226, doi:10.1016/S0924-7963(98)00013-X, 1998.

Stöven, T.: Ventilation processes of the Mediterranean Sea based on CFC-12 ad $\mathrm{SF}_{6}$ measurements, Diploma, Leibniz-Institut für Meereswissenschaften der Mathematischnaturwissenschaftlichen Fakultät, Christian-Albrecht-Universität zu Kiel, Kiel, 2011.

Stöven, T. and Tanhua, T.: Ventilation of the Mediterranean Sea constrained by multiple transient tracer measurements, Ocean 
Sci. Discuss., 10, 1647-1705, doi:10.5194/osd-10-1647-2013, 2013.

Sültenfuß, J., Roether, W., and Rhein, M.: The Bremen mass spectrometric facility for the measurement of helium isotopes, neon, and tritium in water, Isot. Environ. Healt. S., 45, 83-95, doi:10.1080/10256010902871929, 2009.

Tanhua, T., Waugh, D. W. and Wallace, D. W. R.: Use of SF 6 to estimate anthropogenic $\mathrm{CO}_{2}$ in the upper ocean, J. Geophys. Res., 113, C04037, doi:10.1029/2007JC004416, 2008.

Tanhua, T., van Heuven, S., Key, R. M., Velo, A., Olsen, A., and Schirnick, C.: Quality control procedures and methods of the CARINA database, Earth Syst. Sci. Data, 2, 35-49, doi:10.5194/essd-2-35-2010, 2010.

Tanhua, T., Waugh, D. W., and Bullister, J. L.: Estimating changes in ocean ventilation from early 1990s CFC-12 and late 2000s SF 6 measurements, Geophys. Res. Lett., 40, 927-932, doi:10.1002/grl.50251, 2013

Theocharis, A., Klein, B., Nittis, K., and Roether, W.: Evolution and status of the Eastern Mediterranean Transient (19971999), J. Marine Syst., 33-34, 91-116, doi:10.1016/S09247963(02)00054-4, 2002.
Vollmer, M. K. and Weiss, R. F.: Simultaneous determination of sulfur hexafluoride and three chlorof luorocarbons in water and air, Mar. Chem., 78, 137-148, 2002.

Waugh, D. W., Hall, T. M., and Haine, T. W. N.: Relationships among tracer ages, J. Geophys. Res., 108, 3138, doi:10.1029/2002JC001325, 2003.

Waugh, D. W., Haine, T. W. N., and Hall, T. M.: Transport times and anthropogenic carbon in the subpolar North Atlantic Ocean, Deep Sea Res.-Pt. I, 51, 1475-1491, doi:10.1016/j.dsr.2004.06.011, 2004.

Weiss, W. and Roether, W.: The rates of tritium input to the world oceans, Earth Planet. Sc. Lett., 49, 435-446, doi:10.1016/0012821X(80)90084-9, 1980

Wüst, G.: On the vertical circulation of the Mediterranean Sea, J. Geophys. Res., 66, 3261-3271, doi:10.1029/JZ066i010p03261, 1961. 